Website: http://journal.umy.ac.id/index.php/mrs

DOI: $10.18196 / \mathrm{jmmr} .8185$

\title{
Is buying behavior influenced by segmentation?
}

Tita Hariyanti*, Harun Al Rasyid**, Anisa Ramadhani Kusumastiti***

* Correspondence Author: tita.hariyanti@gmail.com

* Faculty of Medicine, University of Brawijaya, Malang, East Java

** Faculty of Medicine, University of Brawijaya, Malang, East Java

*** Institut Ilmu Kesehatan, Kediri, East Java, Indonesia

\section{N D E X I N G}

Keywords:

Buying Behavior;

Influence;

Segmentation;
Kata Kunci:

Buying Behavior;

Pengaruh;

Segmentasi;

\begin{abstract}
A B S T R AC T
Buying behavior in choosing health care is a long process. Segmentation is one of the things that underlie the decision of the patient. This study aims to determine the buying behavior of patients who do the first child labor and its relationship with buying behavior in RSIA Puri Bunda (PB) Malang. This research use cross sectional method. The sampling technique used the total sampling method, i.e. all inpatients that gave birth to the first child at the time of this study were executed. The number of samples was 55 respondents in April-May 2017. Data were analyzed using multinomial logistic regression. The results showed that customer segmentation of RSIA PB was from Blimbing subdistrict, 21-25 years old, last high school education, income $<$ Rp.1.500.000,00, housewife, Islam, class of 3rd class and payment method using BPJS . Buying behavior of respondents is included in complex type and dissonance reducing buying behavior. Geographic, demographic, psychographic and behavioral segmentation is not related to buying behavior. Segments that have been detected are expected to get attention from the hospital to determine the marketing efforts that will be done next. In its marketing efforts, RSIA PB should pay more attention to customers who have a highinvolvement type in order to provide all the information expected by the customer.
\end{abstract}

Buying behavior dalam memilih layanan kesehatannya merupakan sebuah proses yang panjang.Segmentasi merupakan salah satu hal yang mendasari pengambilan keputusan dari pasien. Penelitian ini bertujuan untuk mengetahui buying behavior pasien yang melakukan persalinan anak pertama dan hubungannya dengan buying behavior di RSIA Puri Bunda (PB) Malang. Penelitian ini menggunakan metode cross sectional. Teknik pengambilan sampel menggunakan metode total sampling, yaitu seluruh pasien rawat inap yang melahirkan anak pertama pada waktu penelitian ini dijalankan. Jumlah sampel sebesar 55 responden pada April-Mei 2017. Data dianalisis menggunakan regresi logistik multinomial. Hasil penelitian menunjukkan bahwa segmentasi pelanggan RSIA PB adalah berasal dari Kecamatan Blimbing, usia 21-25 tahun, pendidikan terakhir SMA, pendapatan $\leq$ Rp.1.500.000,00, ibu rumah tangga, agama Islam, kelas perawatan kelas 3 dan cara pembayaran mengunakan BPJS. Buying behaviorresponden termasuk dalam tipe complex dan dissonance reducing buying behavior. Segmentasi geografis, demografis, psikografis dan tingkah laku tidak berhubungan denganbuying behavior. Segmen yang telah terdeteksi diharapkan mendapatkan perhatian dari rumah sakit untuk menentukan usaha pemasaran yang akan dilakukan selanjutnya. Dalam usaha pemasarannya, RSIA PB harus lebih memperhatikan pelanggan yang mempunyai tipe keterlibatan tinggi sehingga dapat memberikan seluruh informasi yang diharapkan oleh pelanggan tersebut.

(C) 2019 JMMR. All rights reserved

Article history: Received 2019-Feb-13; Revised 2019-Apr-15; Accepted 2019-Apr-25

\section{INTRODUCTION}

Hospitals must face many changes in the market, including changes in laws and regulations by the government, intense competition and increasingly critical service users. ${ }^{1,6}$ A very tight competition can be responded to by hospitals by improving service quality and increasing marketing. Marketing efforts include nine marketing elements, namely segmentation, targeting, positioning, differentiation, marketing mix (product, place, promotion, and price), selling, brand, service and process. ${ }^{14}$ Segmentation as the initial stage of the 9 elements must be done by an organization in order to understand the target market. Broadly speaking, segmentation can be done based on demography, geography, psychography and behavior. $\frac{18}{-}$ This segmentation can affect health seeking behavior (health seeking 
behavior). When someone then has a good health seeking behavior and is aware that he needs hospital services, it will influence the choice of one or more services (buying behavior) in the hospital. $\stackrel{14}{ }$

Kotler says buying behavior refers to the behavior of the final purchase of consumers who buy goods and services for personal consumption..$^{14}$ There are four types of buying behavior, namely complex, dissonance-reducing, variety-seeking and habitual buying behavior. Type of buying behavior can be influenced by the segmentation described from the characteristics of the buyer, the process of purchasing decisions, individual behavior, family, social, and cultural environment.

From preliminary studies conducted at the obstetrics and obstetric clinic, data were obtained that $40 \%$ of patients who ante natal care (ANC) in the obstetric and obstetric clinic chose not to deliver at the RSIA PB. The decision not to choose RSIA PB as a place of delivery can be influenced by several things, including location and distance. Munandar states that location and distance affect the community to use health services (buying behavior). ${ }^{17}$ Buying behavior can reveal the strengths and weaknesses of the marketing process carried out by the company. ${ }^{20}$ Buying behavior also signals a consumer's retention of a product or not. ${ }^{15}$

It is expected that by knowing the type of buying behavior of patients who deliver at RSIA PB can help hospital management to know the characteristics of their patients and determine the right marketing strategy.

\section{RESEARCH METHOD}

This study uses a quantitative non-experimental research approach in the form of a survey with a cross sectional method. The study was carried out at the inpatient installation. The populations taken in this study were mothers who gave birth to the first child during April-May 2017. The selection of respondents was based on the consideration that mothers who will give birth to first children have a more varied type of buying behavior. The sampling technique uses the total sampling method, which are 55 respondents. The independent variables of the study were geographical segmentation, demographic segmentation (age, occupation, income, religion, and education), psychographic segmentation and behavioral segmentation. The dependent variable of research is buying behavior, namely a complex decision making behavior, dissonance-reducing buying behavior, variety-seeking buying behavior and habitual buying behavior. Data collection uses a questionnaire that has been tested for validity and reliability. Data analysis used is multinomial logistic regression.

\section{RESULT AND DISCUSSION}

\section{Customer Characteristics}

The respondents of this study mostly chose to use class 3 as their care class $(65.5 \%)$ and chose the method of payment with BPJS (69.1\%).
Characteristics of respondents are presented in the following table:

Tabel 1. Responden Characteristic $(n=55)$

\begin{tabular}{|c|c|c|c|}
\hline \multicolumn{2}{|c|}{ Responden Characteristic } & \multirow[t]{2}{*}{ Total } & \multirow[t]{2}{*}{$\%$} \\
\hline Address & Kedungkandang & & \\
\hline & District & 13 & $23,6 \%$ \\
\hline & Blimbing District & 15 & $27,3 \%$ \\
\hline & Klojen District & 6 & $10,9 \%$ \\
\hline & Sukun District & 9 & $16,4 \%$ \\
\hline & Malang District & 12 & $21,8 \%$ \\
\hline \multirow[t]{4}{*}{ Age } & $\leq 20$ Year & 5 & $9,1 \%$ \\
\hline & $21-25$ Year & 35 & $63,6 \%$ \\
\hline & 26 - 30 Year & 9 & $16,4 \%$ \\
\hline & $>30$ Year & 6 & $10,9 \%$ \\
\hline \multirow{8}{*}{$\begin{array}{l}\text { Highest } \\
\text { education level }\end{array}$} & Primary School & 2 & $3,6 \%$ \\
\hline & Junior High & & \\
\hline & School & 3 & $5,5 \%$ \\
\hline & Senior High & & \\
\hline & School & 26 & $47,3 \%$ \\
\hline & Diploma & 10 & $18,2 \%$ \\
\hline & S1 & 14 & $25,5 \%$ \\
\hline & $\mathrm{S} 2 / \mathrm{S} 3$ & 0 & $0,0 \%$ \\
\hline \multirow[t]{4}{*}{ Job } & Housewife & 26 & $47,3 \%$ \\
\hline & PNS & 12 & $21,8 \%$ \\
\hline & BUMN / Swasta & 10 & $18,2 \%$ \\
\hline & Wiraswasta & 7 & $12,7 \%$ \\
\hline \multirow[t]{8}{*}{ Payment/month } & $\leq 1.500 .000$ & 18 & $32,7 \%$ \\
\hline & $1.500 .000-$ & & \\
\hline & 2.500 .000 & 16 & $29,1 \%$ \\
\hline & $2.500 .000-$ & & \\
\hline & 3.500 .000 & 15 & $27,3 \%$ \\
\hline & $3.500 .000-$ & & \\
\hline & 4.500 .000 & 1 & $1,8 \%$ \\
\hline & $>4.500 .000$ & 5 & $9,1 \%$ \\
\hline \multirow[t]{2}{*}{ Religion } & Islam & 49 & $89,1 \%$ \\
\hline & Non Islam & 6 & $10,9 \%$ \\
\hline \multirow[t]{3}{*}{ Type of room } & Class Number 1 & 7 & $12,7 \%$ \\
\hline & Class Number 2 & 12 & $21,8 \%$ \\
\hline & Class Number 3 & 36 & $65,5 \%$ \\
\hline \multirow{2}{*}{$\begin{array}{l}\text { Payment } \\
\text { method }\end{array}$} & BPJS & 38 & $69,1 \%$ \\
\hline & Umum & 17 & $30,9 \%$ \\
\hline
\end{tabular}

\section{Sources of data: research, 2017}

Respondents who chose to deliver the first child in RSIA PB came from Blimbing District (27.3\%), aged between 21-25 years (63.6\%), last educated high school (47.3\%), had monthly income of $<1,500,000$, which was housewives $(47.3 \%)$ and Muslims (89.1\%).

From the results of the descriptive analysis of the 4 types of buying behavior, we find that the results of complex decision making are the most dominant type (40\%) among the other types. Data shows that the first childbirth mother has a complex type of decision making buying behavior compared to other types, 
namely dissonance reducing buying behavior, variety seeking buying behavior and habitual buying behavior. Determination of the type of buying behavior can be measured from the frequency of information seeking, consideration of comfort, quality, rates, doctors, facilities to the way of payment, as well as the time needed to consider all these aspects.

Multinomial logistic regression analysis is intended to determine the influence of geography, age, education, income, employment, religion, psychographics and behavior on buying behavior. The results of testing the goodness of fit show a probability of 0.202 , or greater than the level of significance (= $5 \%$ ), so that it can be stated that the model formed capable or feasible is used to predict the relationship between the independent variable and the dependent variable.

The size of the geographical contribution, age, education, income, employment, religion, psychographics and behavior towards buying behavior can be known through the coefficient of determination (Nagelkerke R2) with the results of 0.515 or $51.5 \%$. This shows that the geographical contribution, age, education, income, employment, religion, psychographics and behavior towards buying behavior is $51.5 \%$ while the remaining $48.5 \%$ is a contribution from other variables not discussed in this study.

Significance testing simultaneously produces a chi-square value of 35.312 with a probability of 0.639 . The test results show a probability greater than the level of significance $(=5 \%)$, which means there is no simultaneous significant effect of geography, age, education, income, employment, religion, psychography and behavior on buying behavior.

Tabel 2. Test results of partial significance

\begin{tabular}{lccc}
\hline \multicolumn{1}{c}{ Variabel } & \multicolumn{3}{c}{ Likelihood Ratio Test } \\
Chi & Dquare & Sf & Sig. \\
\hline Age & 4,953 & 3 & 0,175 \\
Religion & 6,582 & 3 & 0,086 \\
Highest education & 0,370 & 3 & 0,946 \\
level & 2,464 & 3 & 0,482 \\
Income per month & 3,829 & 9 & 0,922 \\
Job & 20,369 & 1 & 0,060 \\
Geographic & 3,012 & 3 & 0,390 \\
Psychographic & 1,886 & 3 & 0,596 \\
Behavior & & & \\
\hline
\end{tabular}

Sources of data: research, 2017

Testing the partial significance of age, religion, education, income, employment, geography, psychography and behavior towards buying behavior more than level of significancy $(=5 \%)$. This means that there is not one segmentation variable that has partial effect on buying behavior.

\section{Customer Segmentation RSIA Puri Bunda}

Childbirth is a good choice when examining a patient's buying behavior compared to other cases of illness because a mother has a long time to consider and choose a hospital to deliver. Factors that influence a consumer's repurchase decision are influenced by product quality, promotion intensity, perceived price and customer loyalty. $.11, \underline{15}$ Patients who gave birth to the first child still had not experienced delivery services at RSIA PB so that the factors that might influence the repeat purchase decision had not affected the type of buying behavior. ${ }^{2}$

The results of the geographical segmentation of this study are that most of the respondents came from Blimbing and Kedungkandang Subdistricts and Malang Regency areas which were directly adjacent to the PB RSIA location. This can be caused by the location of the hospital in Blimbing District which borders the District of Kedungkandang and Pakis, Malang Regency. Proximity and ease of access from living quarters to health facilities can indeed influence the selection of birth attendants $^{12}$. What can be done by RSIA PB is to expand cooperation in Blimbing District through first-level health facilities and the practice of private doctors or midwives. Collaboration can be done by providing financial or non-financial rewards. Non-financial rewards can be realized by inviting or including referrers in activities conducted by RSIA PB, such as seminars or hospital birthday events. Another possible action is to install billboards as a guide to get to the location of the RSIA Puri Bunda which is not on the edge of the highway.

Demographic segmentation is done by grouping respondents according to age, religion, education, income per month, and work. Most segments are between the ages of 21-25 years or a group of young adults who generally have a family, work, and can make their own decisions ${ }^{16}$ and are in accordance with the ideal age for pregnancy and childbirth. In addition to young adults, the majority of respondents is the last high school education level. Education achieved by a consumer usually determines income, social class and intellectual level of a person who will influence his decision in choosing a product which in this case is the selection of inpatient services in a hospital. ${ }^{10}$ The use of technology can be applied to groups with secondary and high education, for example by using SMS and the internet. $\frac{16}{}$ Someone aged 14-35 years tends to be brave and more open to new ideas that emerge. The media that is most often accessed by this segment is the internet. Unlike other segments, the use of internet media defeats other media such as television.

At present all activities of a young adult, such as school, socializing, activities at home or on the trip, cannot be separated from the internet. ${ }^{7}$ Netizens or people who are active in the online world are very potential markets, those who communicate with one another, recommend one another with each other both through social media and existing forums. ${ }^{-}$It is important for hospitals to improve the constantly updated hospital website, starting with the doctor's schedule of practice, outpatient registration, available services, until the current promo. The SMS 
media can also be used by hospitals to disseminate health information, products owned by RSIA Puri Bunda, doctor's practice schedule to notify activities that will be or are being carried out at RSIA Puri Bunda. Media SMS can also be used to make a special approach to patients for example to remind patients of control schedules or usual care schedules for patients.

Most RSIA Puri Bunda patients have a monthly income of $<$ Rp. $1,500,000.00$ and between Rp. 1,500,000.00 - Rp. $2,500,000.00$. This means that the majority of RSIA PB patients are patients in the middle-low economy category. ${ }^{-}$Patients with low economic status tend to choose or use affordable and inexpensive health services..$^{21}$ This middle and lower economic segment can be responded to by hospitals for example by disseminating tariffs for facilities, services and programs owned. Promotion can also be done by doing a home visit or using a radio because some people with low income will be difficult to access using internet media.

The number of patients who choose class 3 care classes can be responded to by the hospital by adding rooms or upgrading classes of treatment that are rarely used to grade 3. However, RSIA Puri Bunda has overcome the lack of class 3 care needs by leaving these patients in another treatment class if the treatment third grade room is full. Most of the respondents are Muslim; this is in accordance with the majority of the population of East Java, $96 \%$ of whom are Muslim. ${ }^{3.4}$ RSIA PB is not a hospital with certain religious themes so that patients who come from various religions. The most respondents in this study were housewives. A woman who does not work and is fully under the authority of her husband tends to not have the power to make decisions in her family. This is due to the fact that those who make payments are husbands, the selection of health facilities is done jointly but

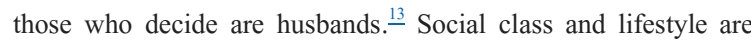
seen in customer preferences in choosing treatment classes. ${ }^{17}$ Most of the respondents chose to use class 3 as their treatment class.

This is in accordance with the level of income of most patients who are in the lower middle class so that grade 3 is a treatment class that best fits the patient's abilities. Patient care classes can show their social class in the community. ${ }^{17}$ Based on the method of payment made, most patients make payments using a third party, namely BPJS insurance. Health services are currently experiencing changes since the implementation of the Health BPJS guarantee, in accordance with the objectives of the BPJS is to make it easier for people to get quality health services Fitriani, 2014. This can be responded to by the hospital by providing a facility to make it easier for patients or families of patients to register or when patients go home, such as providing a photocopy machine. In addition, RSIA PB can also create promotional media such as slideshows displayed on television in the waiting room, banners or posters that show what services or facilities can be used by BPJS participants.

Buying behavior can be identified based on consumer involvement and differentiated into high involvement and low involvement. ${ }^{20}$ Involvement is related to product choice and consumer behavior. Purchasing products with low involvement (causes the occurrence of variations in behavior compared to the purchase of products with high involvement ${ }^{12}$. The results showed that the type of buying behavior based on the highest consumer involvement in customers of RSIA PB was a type of high involvement, namely complex buying behavior and dissonance reducing buying behavior.

In the delivery of the first child, decision making for choosing this hospital is difficult because labor is very important for consumers but consumers does not have prior experience in making this decision. ${ }^{11}$ Consumer uncertainty in making this type of decision requires consumers to be involved in an extensive decision-making process or high involvement. Usually consumers with the type of complex buying behavior must try to find out a product or service if they do not know it. Therefore, marketers must develop strategies to provide information to consumers about product attributes, interests, about company brands, and other important attributes. ${ }^{-}$In addition to the complex type, most customers of the next RSIA PB are consumers with high involvement type dissonance-reducing buying behavior. Consumers with this type realize there are only a few differences between various brands. Before making a purchasing decision, consumers will look for information then make purchases based on one or two things that are considered most important such as prices or those that provide comfort. $\frac{14}{}$

The thing that can be done by the hospital with this type of patient is by providing and facilitating access from all the information needed by the patient when looking for a place to deliver. Facilities that can be provided can be in the form of care manuals during pregnancy and childbirth at Puri Bunda Hospital covering all available facilities, doctor's schedule, photos of treatment classrooms, security systems, up to room rates per day for non-insurance patients. In addition, hospitals can also provide customer service and special rooms for mothers who seek information about labor at Puri Bunda Hospital so that all information needed by high-involvement consumers can be well accommodated. Patients who seek information through telephone media can also be facilitated by connecting these patients to assigned customer service.

In addition to the high involvement type, from the results of the study there are also consumers of RSIA PB who have a low type of involvement, namely the type of variety seeking buying behavior and type of habitual buying behavior. Information seeking, and evaluation of products or services purchased on purchases that have low involvement is more limited than high 
involvement ${ }^{11}$. Types of variety seeking buying behavior usually occur in consumers who often change brands because they are bored and try other brands. Variation seeking behavior usually occurs if the risk is small.

Some types of variety seeking consumers have buying behavior characteristics like trying, trying done by others, and paying attention to the latest innovations. ${ }^{10}$ In addition, differences in perceptions between brands, hedonic features, and strength of preferences also influence consumer behavior in seeking variation. Although most customers are of high involvement type, there are also types of customers with low involvement. For variety seeking types, RSIA Puri Bunda can create and offer the latest innovations that are distinctive and not found in other hospitals and are expected to become permanent consumers of RSIA Puri Bunda. The interior of RSIA Puri Bunda has a Balinese nuance; this can be utilized by hospitals by adding to the existing Balinese nuances such as by adding Balinese music in outpatient areas or family waiting rooms for inpatients of hospitals.

The least common type found in this study is the type of patient with low involvement habitual buying behavior. Consumers with habitual buying behavior will buy a product based on habits, not based on loyalty to the brand. Consumers return to buying the same product or service without thinking too much about other products. Consumers feel confident in making their purchasing decisions because they have experience buying previous products ${ }^{1}$. Marketers can make involvement between products and consumers, for example by creating products that involve personal situations or emotions through advertising. ${ }^{8}$ For consumers with the type of habitual buying behavior, RSIA Puri Bunda can create special programs for consumers who often do maintenance and utilize services at RSIA Puri Bunda. One example is to provide product offers related to mothers and babies such as baby spas, pregnancy exercises or postpartum spas at low prices.

\section{Segmentation Relationships with Buying Behavior}

Buying behavior is focused on the way a person makes a decision to use all his time, money and energy to make a purchase, including considering the goods to be purchased, buying reasons, buying time, frequency of purchases, evaluation after purchase and the effect of evaluating current purchases next. Several factors can influence a person's buying behavior, including cultural, social, personal and psychological factors. Personal factors include variables of age, education, work, income, lifestyle, religion..$^{19}$

Analysis of the coefficient of determination shows that the contribution of geographic segmentation, demographic segmentation, psychographic segmentation and behavior segmentation to the buying behavior is $51 \%$. The rest are contributions from other variables, including cultural factors which include consumer culture, subculture and social class. Then social factors, namely the influence of other people on consumers, and psychological factors include motivation, perception, learning, trust and attitude..$^{19}$

The results of the research and statistical analysis found that geographic segmentation, demographic segmentation, psychographic segmentation and behavior segmentation together did not show a meaningful relationship with buying behavior. The patient gave birth to the first child seen from consumer involvement in PB RSIA. Statistical analysis also shows that geographic segmentation, demographic segmentation, psychographic segmentation and behavior segmentation are partially unrelated to buying behavior of patients giving birth to the first child seen from consumer involvement in RSIA Puri Bunda. This segmentation is a grouping of patients based on variables that influence buying behavior based on personal factors.

Results that are not influential between segmentation on buying behavior can be caused by a lack of the number of samples carried out in this study. Samples that are too small can cause research to not describe the true condition of the population. Initially the sample plan used using the infinite sample calculation was 86 samples. After walking the research to exceed the research deadline, the sample was not in accordance with the calculations, so that all respondents who were present at the time.

\section{CONCLUSION}

The conclusion of this study is that the customer segmentation of RSIA PB originates from Blimbing District, ages 21-25 years, senior high school education, income $<$ Rp.1,500,000.00, housewives, Islam, class 3 care classes and how to pay using BPJS. Buying behavior of patients who deliver the first child in RSIA Puri Bunda is dominated by the type of high involvement, namely the type of complex buying behavior and dissonance reducing buying behavior. And after the analysis, there is no influence of geographical, demographic, psychographic segmentation and behavior towards noise behavior both simultaneously and partially.

From these conclusions, the researchers suggested that hospitals RSIA PB pay more attention to customers who have high involvement types so that they can provide all the information expected by the customer. Researchers feel the need to conduct further research on other factors besides those that can influence buying behavior

\section{REFFERENCE}

1. Arief, M dan Sudikno, S. (2014). Determinan Pemilihan Persalinan di Fasilitas Kesehatan (Analisis Data Riset Kesehatan Dasar tahun 2010). Jurnal Kesehatan Reproduksi, vol. 5, no. 3, pp. 145-154. 
2. Babu, MG, Vani, G \& Panchanatham, N. (2010). Consumer Buying Behaviour.

3. Badan Pusat Statistik. (2010) Sensus Penduduk Infonesia 2010.

4. Badan Pusat Statistik. (2016) Kota Malang dalam angka. Badan Pusat Statistik Kota Malang

5. Fenzuma, H., Trimur, Y., Herdiana E., Nurcahyo, K., \& Utomo CB. (2009). Konseling Gizi pada Ibu dari Balita Gizi Buruk di Kelurahan Pengasinan, Kecamatan Sawangan, Kota Depok dalam Upaya Perbaikan Gizi Balita.

6. Fitriani, S. (2014). Pengaruh Kualitas Pelayanan terhadap Loyalitas melalui Kepuasan Pasien Pengguna BPJS di Rawat Inap RSUD Dr. Moewardi. Universitas Muhammadiyah Surakarta.

7. Harun, HM., \& Abdullah AZ. (2014). Hubungan Karakteristik dan Perilaku ibu dengan Status Persalinan di Wilayah Pesisir Kecamatan Tallo, Makassar.

8. Japarianto, E. (2006). Analisis Pembentukan Disonansi Kognitif Konsumen Pemilik Mobil Toyota Avanza. Jurnal Manajemen Pemasaran, vol. 1, no. 2.

9. Junaedi, MS. (2015). Pengaruh kesadaran lingkungan pada niat beli produk hijau: Studi perilaku konsumen berwawasan lingkungan. Benefit: Jurnal Manajemen dan Bisnis, vol. 9, no. 2, pp. 189-201.

10. Junaedi, MS. (2016). Analisis faktor demografi, akses media dan sumber informasi terhadap kepedulian dan kesadaran lingkungan konsumen: kajian pemasaran yang berwawasan sosial. Kinerja, vol. 7, no. 2, pp. 96-111.

11. Junaidi, Shellyana, Dharmmesta \& Swastha, B. (2015). Pengaruh ketidakpuasan konsumen, karakteristik kategori produk, dan kebutuhan mencari variasi terhadap keputusan perpindahan merek. Journal of Indonesian Economy and Business, vol. 17, no. 1.

12. Khaniwale, M. (2015). Consumer Buying behavior. International Journal of Innovation and Scientific Research, vol. 14, no. 2, pp. 278-286.

13. Kiranantika, A. (2015). pola pengambilan keputusan mengenai partisipasi dalam program keluarga berencana pada keluarga muda di Kota Malang. Jurnal Sejarah dan Budaya, vol. 7, no. 1, pp. 51-61.

14. Kotler, P.(2009). Manajemen Pemasaran. Erlangga, Jakarta

15. Kurniawan, I, Santoso, SB \& Dwiyanto, BM.(2007). Analisis Faktor-faktor yang Mempengaruhi Minat Beli Ulang Produk serta Dampaknya terhadap Loyalitas Pelanggan (Studi Kasus pada Produk Sakatonik Liver di Kota Semarang). Jurnal Studi Manajemen Organisasi, vol. 4, no. 2, pp. 20-29.

16. Mulyono, A. (2009). Analisis Segmen, Target, Posisi Pasar, dan Alternatif Diferensiasi Layanan di Instalasi Rawat Inap Umum RS Karya Husada Cikampek Tahun 2009.

17. Munandar, D.(2005). Analisis Penentuan Segmen, Target, dan Posisi Pasar Home Care di Rumah Sakit AL-ISLAM Bandung. Universitas Komputer Indonesia, vol. 6.
18. Rovitasari, M, Utami, S, Sandra, S \& Christyana.(2013). Analisis Segmentasi Pasar Pengguna Jasa Pelayanan Rawat Inap Rumah Sakit Daerah Kalisat Tahun 2013.

19. Singh, A \& Dhayal, N.(2014). Consumer Buying Behaviour. International Research Journal of Management Sociology \& Humanity ( IRJMSH ), vol. 5, no. 12.

20. Tambunan, DB.(2012). Atribut Yang Menjadi Pertimbangan Konsumen Dalam Membeli Produk Perumahan Penelitian Dan Analisis Conjoint. International research journal of business studies, vol. 2, no. 2 .

21. Wahdi, N.(2006).Analisis Faktor-Faktor yang Mempengaruhi Kepuasan Pasien sebagai Upaya Meningkatkan Loyalitas Pasien (Studi empiris pada Rumah Sakit Panti Wilasa "Citarum" Semarang). Program Pasca Sarjana Universitas Diponegoro. 